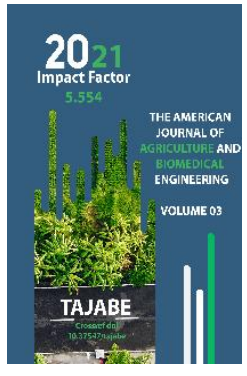

Journal Website: http://theamericanjour nals.com/index.php/taj abe

Copyright: Original content from this work may be used under the terms of the creative commons attributes 4.0 licence.

\section{Bioecology And Prospects Of Essential Oil And Medicinal Plants Cultivation In Surkhandarya Region}

\author{
Begmatov Abdusamat \\ Ph.D., Assoc. TerDU Associate Professor, Uzbekistan \\ Ganieva Gulirukhsor \\ TerDU First Year Master Student of Biology/ Botany, Uzbekistan
}

\title{
ABSTRACT
}

It is emphasized that the role of natural remedies in the treatment of some diseases is invaluable in the process of medical reform. Therefore, large-scale measures are being taken in our country on the basis of state programs to increase the number of medicinal plants and organize their processing said President Shavkat Mirziyoyev. At the suggestion of Mirziyoyev, tasks are being given to establish plantations of medicinal plants in certain regions of the country and process them. During the visit of the President to the Surkhandarya region, these proposals on the effective use of existing opportunities in the region, especially in the desert and mountainous areas, will open a new stage in the work on the cultivation of medicinal plants.

\section{KEYWORDS}

Medicinal plants, lavender, stevia, medicinal valerian, lavandula angustifolia L, lamiaceae Lind L. less common. The sap, roots, stems and leaves of

\section{INTRODUCTION}

In the territories of Tashkent, Surkhandarya, Kashkadarya, Samarkand, Bukhara, Jizzakh and Navoi regions and the Republic of Karakalpakstan, mainly sandy deserts, hills, mountains and foothills, on clean soils, it is

essential oils are used in pharmaceuticals and the drugs extracted from them are widely used in the treatment of different human sicknesses. Therefore, the representatives of 
essential plants in our country are protected by the state. Introduction of medicinal plants not only reduces the cost of imported raw materials, but also enriches the biodiversity of the local environment and partially satisfies the demand of the population for medicinal plants [2]. Essential oil is a mixture of volatile organic substances that are extracted from plants with the help of water vapor and have a unique odor and taste. Aromatic plants and some products derived from them (essential oils, resins and essential oils from plants containing essential oils) have been known so long ago.

The study of medicinal plants belongs to the flora of Uzbekistan, as well as the introduction and acclimatization of medicinal plants belonging to other flora, the provision of the pharmaceutical industry with local raw materials and medicinal products. At present, the basis of medicines in official medicine is the raw materials obtained from medicinal plants. Due to the fact that medicines made from medicinal plants are harmless to the human body, the habitat of medicinal plants is shrinking in nature due to the growing demand of the population for them. For this reason, it is important to cultivate food and medicinal plants in culture, to study their bio morphological properties, chemical composition, introduction and development of science-based cultivation technology [4].

The purpose of the research is the introduction and acclimatization of medicinal essential oils of lavender, stevia, medicinal valerian, medicinal herbs in the soil and climatic conditions of Surkhandarya region. The high quality and effectiveness of the essential oil coincides with the budding and flowering of most plants. In this case, the surface mass of the plant should be removed. When the buds and flowers are full and the seeds and fruits are fully ripe, the roots, rhizomes, tubers and corms are harvested at the end of the growing season, before the plant goes to sleep.

\section{LITERETURE VIEW}

Medicinal plant lavender (lavandula angustifolia L), lavender (Lavandula) family, mint - lamiaceae Lindl. Semi-shrub belonging to the family homeland lavender - the Mediterranean. In nature, lavender grows from the shores of the Mediterranean to Old India. High-quality lavender species grow at an altitude of 700 to 1,400 meters above sea level. Wide spread in Europe, North and South Africa, mountainous and tropical regions of Asia, America and Australia.

The history of lavender in Russia dates back to the 30 s of the 18th century, when Peter the Great established a botanical garden in St. Petersburg. In Uzbekistan, lavender was brought from the Sukhumi Botanical garden in 1930, and the imported seedlings were planted in the botanical garden of the Central Asian State University. Currently, it is grown in the "Laboratory of medicinal plants" of the Tashkent botanical garden.

Medicinal lavender is widely used in European countries, not only for cosmetology and pharmaceuticals, but also for landscaping, architecture of gardens and alleys, and is widely used in folk medicine. Lavandula angustifolia fruit is dry, 4 single-seeded dark brown nuts, small, smooth, oblong-oval, seeds 
$0.03 \mathrm{~cm}$ long and $0.02 \mathrm{~cm}$ wide, 1000 seeds weigh 1-1.3 gr.

The most important biological properties of plant seeds are the formation of the seed, the course of physiological processes that take place in them. Plant life begins with the germination of seeds and ends with the formation of seeds. Whether or not the plant phase is complete depends on the ecological characteristics of the area where it is grown. Lavender angustifolia seeds germinate at 11$32.2^{\circ} \mathrm{C}$ in 2-3 weeks. According to Tukhtaev, it is recommended to sow the seeds in open area in the spring, when the temperature is 16 ${ }^{\circ} \mathrm{C}-21^{\circ} \mathrm{C}$. Seed germination at home was studied under two different conditions. A mixture of humus and gray soil, as well as 100 seeds of lavandula angustifolia were planted in peat.

In the city of Termez, Surkhandarya region, lavandula angustifolia seeds, grown in climatic and soil conditions, germinate in 8 to14 days after sowing. In a mixture of humus and gray soil, the seeds germinated in 21 days and in peat in 12 days. It is recommended to grow lavendula angustifolia, given that the average germination of seeds in peat is more than $76 \%$ and the stages of ontogeny continue.

Medicinal plant salvia officinalis $L$ is a perennial, semi-shrub up to $20-50 \mathrm{~cm}$ in height. The stems are numerous, branched, deciduous, four-sided, the lower part is slightly woody. The leaves are simple, with a long band, the upper part of the stem is without a band, and the stem is opposite. The flowers are short-banded, small on the upper part of the stems and branches form a spherical circle. The flower has a curved inflorescence with two labia, the petals have two labia, the maternal node has four lobes, located at the top (Fig. 16). The fruit consists of 4 nuts. It blooms in June-July. Its homeland is mediterranean countries. It is grown in Moldova, Ukraine, Krasnodar Krai and Crimea. Medicinal preparations of this plant are leafs used as a laxative, disinfectant and antiinflammatory drug for inflammation of the upper respiratory tract, for rinsing the mouth (stomatitis and gingivitis) and throat.

Medicine preparation: Marmarak leaves are used in the treatment of inflammation of the throat, chest, upper respiratory tract, gastric diseases and diarrhea - teas and bronchodilators. The drug "Salvin" is obtained from the leaves of Marmarak. Its $0.1-0.25 \%$ solutions in water or isotonic sodium chloride solution are used in the treatment of chronic inflammatory diseases of the oral cavity (gingivitis, stomatitis, periodontitis), purulent, tropical and bone ulcers.

Medicinal product of valeriana officinalis L: This plant belongs to the floristic oasis of the circumboreal (Central and Eastern Europe) and East Asia (Far East) in terms of geographical distribution. In Uzbekistan, a medicinal plant is an introductory plant. Drugs are used as sedatives, cardiovascular enhancers in insomnia, various forms of headache, early forms of angina, increased central nervous system [1].

\section{CONCLUSION}

Research is underway to introduce stevia rebaudiana Bertoni into the climate and production of stevia rebaudiana in the southern Surkhandarya region of Uzbekistan 
[3]. The entry of plants into the generative period is one of the main criteria for determining their climate. The studied S. rebaudiana plant in the conditions of Surkhandarya region started the generative period in the first growing year [5]. They usually bloom much later, in early September. As a result, it produces high quality seeds and multiplies better than seeds [6]. The methods of reproduction and cultivation we recommend can be used by farms that grow $\mathrm{S}$. rebaudiana.

\section{REFERENCES}

1. Abdunazarov E.E. Introduction and bioecological features of Valeriana officinalis L. in the conditions of the Tashkent oasis. diss. ... Cand. biol. sciences. -Tashkent: AN RUz. 2010.

2. Ashurmetov O. A., Tukhtaev B. Ye. Dorivor имsimliclarintroductionsining Tarihi, muammolari va istiқbollari // Y̌simlari va istik̨bollari: muammolari va istikbollari: Republic of Ilmiy materiallari conference. -Khiva: KhMA, 2003. - B. 12-15.

3. Begmatov A.M. Bioecological features of Steviarebaudiana Bertoni when introduced in the Surkhandarya region. diss. ... Cand. biol. sciences. Tashkent: AN RUz. 2012.- S. 20.

4. Begmatov A.M., Rakhmatova M.U. Bioecological features of Glycyrrhiza $L$. // Modern research and development, no. 3 (20). Moscow, 2018. -S. 110-113.

5. Begmatov A. M., Sattarov A.S. Bioecological properties of Stevia rebaudiana Bertoni in introduction conditions. The American Journal of Agriculture and Boimedical
Engineering. Volume 2 Issue 10, 2020. P. 63-68.

6. Sattarov A.S., Begmatov A. M. Bioecology of melissa officinalis plant In Introduction conditions. The American Journal of Agriculture and Boimedical Engineering. Volume 2 Issue 10, 2020. -P. 69-73.

7. Tukhtaev B.E. Introduction of medicinal plants on saline lands of Uzbekistan: Author's abstract. dis. ... Doctor of Biological Sciences. Tashkent: IG and EBR AS RUz. 2009.$38 \mathrm{p}$. 